\title{
The Influence of Corporate Governance Mechanism on the Relationship between Related Party Transactions and Earnings Management
}

\author{
Aria Farah Mita, Sidharta Utama \\ Faculty of Economic, University of Indonesia
}

\begin{tabular}{l|l}
\hline A R T I C L E I N F O & A B S T R A C T \\
\hline $\begin{array}{l}\text { Keywords: } \\
\text { Related Party Transactions, } \\
\text { Earnings Management, } \\
\text { Corpotionary Accruals, }\end{array}$ & $\begin{array}{l}\text { The objective of this study is to investigate the relationship between } \\
\text { related party transactions (RPT) and earnings management. This study } \\
\text { argues there is a different influence between RPT a priori likely to result } \\
\text { in expropriation and RPT a priori not likely to result in expropriation. } \\
\text { RPT a priori likely to result in expropriation creates an incentive to } \\
\text { management or controlling shareholder to overstate income to cover } \\
\text { or mask their expropriation. This study uses non-absolute discretionary } \\
\text { accruals based on Kazsnik model to proxy earnings management. } \\
\text { Corporate governance mechanism should reduce the incentive to } \\
\text { overstate income in a company that involves in RPT a priori likely to } \\
\text { result in expropriation. The results of this study show that the earnings } \\
\text { management (income increasing) is affected by the existence of RPT } \\
\text { a priori likely to result in expropriation and corporate governance } \\
\text { mechanism, but it is not affected by the size/value of the transactions. } \\
\text { As expected, companies involving in RPT a priori likely to result in } \\
\text { expropriation with weak corporate governance mechanism, tend to } \\
\text { manage earnings that increase income. We find that strong corporate } \\
\text { governance mechanism decreases the discretionary accruals in } \\
\text { companies which have RPT a priori likely to result in expropriation. }\end{array}$
\end{tabular}

\section{INTRODUCTION}

\section{Background}

Attention to related party transaction recently increased. One was caused by a major fraud involving big company in America, Enron, and ended in bankruptcy. Accounting fraud done by
Enron involving transactions with related parties. These events lead to the regulator to start providing more stringent oversight mechanism for the related party transactions. Users of financial statements considered this related party transaction as an indicator of aggressive accounting. Sherman 
\& Young (2001), identify areas that allow for aggressive accounting, one of them is related party transactions (RPT), which enables the company to arbitrarily increase income.

According to the CFA Institute Report in 2009 about RPT in Asia, stated that the ownership structure of countries in Asia that are highly concentrated, will make RPT becomes very easy to do. Those reports said that RPT is generally used by controlling shareholders to expropriate the minority shareholders' wealth.

RPT are transactions that carried out with related parties such as companies under the same controlling entity, an associated company, key employees, immediate families or individuals or companies that have a significant voting right (Rule No. VIII/2000, The Indonesian Capital Market Regulatory Body). Actually, RPT can be viewed as having an important role in meeting the economic needs of the company (Gordon \& Henry, 2005). In the expansion, the company usually gets financial support from inter-company transactions. Usually this is done because the incentives in terms of lower cost of capital. Noted that because the parties involved in RPT are affiliated parties, then it might be different from ordinary business transactions. The transaction may not be conducted with reasonable price and also there may be conflict of interest.

Transactions that are carried out with insiders (controlling shareholders or management) can create incentives for expropriation, that is, take advantage from corporate profits, using his authority to influence the terms of the transaction in accordance with their personal goals and otherwise, the cost of other shareholders or minority shareholders. Thus, the RPT is not consistent with the objectives of the company to maximize shareholder wealth. When the Executive or the Commissioner participated in the RPT, then they have incentives to manage earnings to increase their personal benefit, or possibly to cover acts of expropriation (Gordon and Henry, 2005).

Not a lot of research that focuses on the relationship between RPT and earnings management. Gordon and Henry (2005) investigated the relationship between RPT and earnings management. The result showed that there was a significant relationship between RPT and earnings management, but only for certain transactions, i.e fixed rate financing from related parties. Research on earnings management in Indonesia have quite a lot, but no one has focused on the relationship between RPT and earnings management. This research is expected to provide empirical evidence about the relationship between the RPT and earnings management in Indonesia.

In the development of earnings management theory, it has been investigated several factors that allegedly become earnings management incentive, including bonus plan hypothesis, debt covenant hypothesis, and improving performance during IPO process. This research contributes in terms of identifying other motivation to earnings management, that is to cover or disguise RPT that apriori likely to result in expropriation done by management or controlling shareholders.

The mechanism of corporate governance (CG) in a company is considered to limit the expropriation of minority shareholder's wealth through RPT, as well as to limit earnings management. Therefore, it will be important to assess the effect of RPT on earnings management by considering corporate governance factor, as a mechanism that could weaken the relationship between the RPT and earnings management. In contrast to research Gordon and Henry (2005), this study not only look at the relationship between the RPT and earnings management, but also will consider the corporate governance mechanisms that influence the relationship between RPT and earnings management. 


\section{Theoretical Framework and Hypothesis}

\section{Development}

According to study of Gordon and Henry (2005), there are two conflicting theories about RPT. The first theory is that RPT contain potential conflicts of interest and can be explained by agency theory from Jensen \& Meckling (1976). RPT contains agency problems between management and shareholders or between the majority shareholders with minority shareholders. On the basis of this theory, RPT can be used by management or controlling shareholder to take personal gain. Thus, this will result incentives to manage earnings to cover the expropriation. The second theory argues that RPT meet the needs of companies and represent an efficient transaction so as to reduce transaction costs. If this happens, then there is no incentive to manage earnings, because none should be covered up.

Although the general view of investors and regulators that RPT can be harmful, but we know that in reality it is not too harmful. As in the research Cheung, et al. (2006) who saw the impact of RPT announcements with abnormal stock return, divided RPT into three groups: (1) transaction that apriori likely to result in expropriation of minority sharholders, among other asset acquisitions, asset sales, stock sales, trade relations, and cash payments (a priori adverse RPT), (2) transactions that likely to benefit minority shareholders, such as cash receipts and relationship between its subsidiaries (a priori not adverse RPT), and (3) transactions with strategic reasons and perhaps not expropriation, such as takeovers and joint ventures, acquisition of joint ventures, and sales among joint ventures (a priori not adverse RPT).

Gordon and Henry (2005) investigated the relationship between RPT and earnings management, and found an association between them, but only for certain types of transactions i.e. transactions of fixed interest loan to related party. Gordon and Henry (2005) came to the conclusion that the existence of increasing RPT is not necessarily an indication that the company engages in earnings management.

According to report from the CFA Institute Asia Pacific in 2009 about RPT in Asia, in addition to accounting standards and regulation of capital markets, corporate governance mechanisms is an important element in investor protection (CFA Institute, 2009). Research Gordon, Henry and Palia (2006) found that in general, the mechanism of weak corporate governance associated with the number of more dollars of RPT. Kohlbeck \& Mayhew (2004) also found that weak corporate governance mechanisms are associated with higher RPT.

This study aims to look at other possible motives in earnings management, that is to disguise or cover losses due to RPT. Thus it can be presumed that the degree of earnings management in companies that involve in RPT will vary with the degree of earnings management in companies that do not involve in RPT. Cheung, et al. (2006), which classifies RPT into three groups discussed earlier, revealed that the company announced apriori adverse RPT will experience significant negative excess return. This study will look at the influence of the existence of various types of RPT (a priori adverse RPT and a priori not adverse RPT) on earnings management, than companies that do not perform these RPT. It can be expected that there will be a higher incentive of earnings management in companies with RPT a priori likely to result in expropriation by increasing the income to cover losses from such transactions, compared with companies that do not perform these RPT. Earnings management proxies with abnormal accruals or discretionary accruals. Thus the first hypothesis is:

H1a: Companies with a priori adverse RPT, will have higher discretionary accruals than companies that do not perform RPT.

H1b: Companies with a priori not adverse RPT, will have different discretionary accruals than 
companies that do not perform RPT.

Corporate Governance (CG) is one of the mechanisms of investor protection. LaFond and Watts (2008) argued the importance of the application of conservative accounting to produce reliable financial statements, do not delay recognition of losses, thereby reducing agency costs. It is believed, that the application of conservatism in the company could ultimately increase shareholder value. CG is seen effectively drive the companies to implement conservatism and prevent acts of aggressive earnings management to increase income (Lara and Osma, 2009). Previous studies perfomed by Chen and Elder (2007) and Liu and Lu (2007) also mentioned that CG mechanism effectively reduces earnings management. Thus, the next hypothesis is:

H1c: CG practices negatively affect discretionary accruals.

As explained earlier that the results of research Gordon \& Henry (2005) showed that not all types of RPT associated with earnings management. Therefore, it can be assumed that different types of RPT will have a different effect on earnings management. By using the classification of RPT by Cheung, et al. (2006), this research is expected to show higher incentives to manage earnings in a company that involve in a priori adverse RPT compared with companies that does a priori not adverse RPT. This happens because a priori adverse RPT likely to have a negative impact to corporate profits. To cover or disguise the loss impact, the company that makes a priori adverse RPT will have an incentive to engage in more income increasing than that of companies that do not conduct a priori adverse RPT. Thus, the next hypothesis is:

H2a: Companies with a priori adverse RPT will have higher discretionary accruals than companies with a priori not adverse RPT.
The value (size) of RPT will certainly have a different effect on earnings management. Consistent with the conflict of interest hypothesis, the greater the value of RPT, the company will make greater income increasing to cover the impact of RPT. This is due to the larger the value of RPT will certainly have a greater impact to profits. Meanwhile, based on the efficient transactions hypothesis, the greater the value of RPT will not create incentive to manage earnings because there is no loss impact that need to be covered. Thus, the next hypothesis is:

\section{H2b: The value (size) of RPT affect discretionary accruals.}

Furthermore, based on a priori theory from Cheung, et al. (2006), which classifies RPT transaction that is a priori adverse RPT and not adverse RPT, it can be presumed that the value (size) of a priori adverse RPT will have a greater positive impact on the degree of earnings management compared to a priori not adverse RPT. Thus the next hypothesis that can be proposed is:

H2c: The effect of value (size) of a priori adverse RPT to discretionary accruals will be more positive than the a priori not adverse RPT.

As discussed earlier that the CG mechanism is considered effectively overseeing the expropriation of the company through RPT. Gordon et al. (2004) and Gao and Kling (2008) found that strong CG mechanism prevent adverse RPT. Thus, the a priori adverse RPT effect on earnings management depends on the mechanism of CG. Companies with a priori adverse RPT and has a weak CG mechanism would be easier to conduct aggressive earnings management than companies without a priori not adverse RPT. While strong corporate governance will reduce the aggressive earnings management, caused by a priori adverse RPT to corporate profits. Thus the next hypothesis that can be proposed is: 
H3a: Companies that involve in a priori adverse RPT with weak CG mechanism, will have a higher discretionary accruals than companies that involve in a priori not adverse RPT.

$\mathrm{H} 3 \mathrm{~b}$ : Companies that involve in a priori adverse RPT with strong CG mechanism will have lower discretionary accruals than companies that involve in a priori adverse RPT with weak CG mechanism.

\section{METHODS}

Samples are listed companies on the Indonesian Stock Exchange (IDX) that announced corporate action which may include transactions with related parties for the years 2005 - 2007, excluding firms in financial services and banking industry. Source data used comes from corporate action, OSIRIS and the financial statements issued by the company. Sample selection criterias are: (1) registered in IDX in 2005 to 2008; (2) has a CG index issued by the Indonesian Institute of Corporate Directorship (IICD); (3) has a fiscal year ending on December 31; and (4) has a complete financial statement data from 2005 to 2008.

There are four differences from previous studies done by Gordon \& Henry (2005). First, this study will look at earnings management level in a period of one year after the announcement of transaction, while Gordon \& Henry (2005) looked at the relationship between the RPT with earnings management in the same period. This is because in a period of one year after RPT, allows the realization of earnings management to cover the impact of losses due to RPT. Second, research Gordon \& Henry (2005) used absolute earnings management measures (absolute discretionary accruals), while this research will see RPT relationship with non-absolute discretionary accruals. The use of absolute discretionary accruals measure earnings management level without regard to whether the earnings management increase or decrease income. Third, this study will look at the influence of the different types of RPT against earnings management. RPT types are grouped using classification Cheung et al. (2006), i.e. a priori adverse RPT and a priori not adverse RPT. A priori adverse RPT will have negative impact on earnings. Thus, companies are expected to engage in earnings management actions that increase income to cover the impact of such losses. This is the reason why this study will use non-absolute earnings management measures. Fourth, these studies take into account the elements of corporate governance practices that allegedly could weaken the relationship between a priori adverse RPT with earnings management.

The hypotheses tests are conducted in two stages, i.e. combined sample of RPT and non-RPT, and subsample of RPT only. To test the first hypothesis, which employ the combined samples of RPT and non-RPT, we use the following model:

DACC $_{i}=\alpha_{0}+\alpha_{1}$ DIRPT $_{i}+\alpha_{2}$ D2RPT $_{i}+\alpha_{3}$ CG $_{i}+$
$\alpha_{4}$ D1YEAR $_{i}+\alpha_{5}$ D2YEAR $_{i}+\alpha_{6}$ D3YEAR $_{i}+\alpha_{7}$ PROF $_{i}$
$+\alpha_{8}$ GROW $_{i}+\alpha_{9}$ LEV $_{i}+\alpha_{10}$ SIZE $_{i}+e_{i} \ldots \ldots \ldots \ldots . . .(a)$

Whereas, DACC = Discretionary accruals; D1RPT = indicator variable of 1 for a priori adverse RPT; $\mathrm{D} 2 \mathrm{RPT}=1$ for a priori not adverse RPT; $\mathrm{CG}=\mathrm{CG}$ index; D1YEAR = 1 for RPT in July 2005 - June 2006, with discretionary accrual in 2006; D2YEAR $=1$ for RPT in July 2006 - June 2007, with discretionary accruals in 2007; D3YEAR $=1$ for RPT in July 2007 - December 2007, with discretionary accruals in 2008 ; Control variable used are: PROF $=$ absolute value of profit changes between $t-1$ to $t$ divided by total assets year $\mathrm{t}$; GROWTH = market value of equity ratio of year $t$ divided by Book Value of Equity of $\mathrm{t}-1$; $\mathrm{LEV}=$ ratio of debt divided by total assets; Ln SIZE = Log Market Value of Equity.

To test the second hypothesis, which employ only the RPT samples, we use the following model:

$$
\begin{aligned}
& \text { DACC }_{i}=\alpha_{0}+\alpha_{1} \text { DRPT }_{i}+\alpha_{2} \text { VRPT }_{i}+\alpha_{3} \text { VRPT }_{-} \\
& \text {DRPT }_{i}+\alpha_{4} \text { CG }_{i}+\alpha_{5} \text { D1YEAR }_{i}+\alpha_{6} \text { D2YEAR }_{i}+ \\
& \alpha_{7} \text { D3YEAR }_{i}+\alpha_{8} \text { PROF }_{i}+\alpha_{9} \text { GROW }_{i}+\alpha_{10} \text { LEV }_{i}+
\end{aligned}
$$


$\alpha_{11} \mathrm{SIZE}_{\mathrm{i}}+\mathrm{e}_{\mathrm{i}}$

Whereas, DACC = Discretionary accruals; DRPT = indicator variable of 1 for a priori adverse RPT; VRPT $=$ value of RPT divided by market value of equity; VRPT DRPT = interaction variable of VRPT with DRPT; $\mathrm{CG}=\mathrm{CG}$ index, we use same control variables as in the model (a).

To test the third hypothesis which employ only RPT samples, we include corporate governance factors that moderate the effects of RPT on earnings management within the following model:

$\mathrm{DACC}_{\mathrm{i}}=\alpha_{0}+\alpha_{1} \mathrm{DRPT}_{\mathrm{i}}+\alpha_{2} \mathrm{VRPT}_{\mathrm{i}}+\alpha_{3} \mathrm{VRPT}_{-}$ $\mathrm{DRPT}_{\mathrm{i}}+\alpha_{4} \mathrm{DCG}_{\mathrm{i}}+\alpha_{5} \mathrm{DRPT}_{-} \mathrm{DCG}_{\mathrm{i}}+\alpha_{6} \mathrm{D} \mathrm{YEAR}_{\mathrm{i}}+$ $\alpha_{7}$ D2YEAR $_{\mathrm{i}}+\alpha_{8}$ D3YEAR $_{\mathrm{i}}+\alpha_{9}$ PROF $_{\mathrm{i}}+\alpha_{10}$ GROW $+\alpha_{11} \mathrm{LEV}_{\mathrm{i}}+\alpha_{12} \mathrm{SIZE}_{\mathrm{i}}+\mathrm{e}_{\mathrm{i}}$

Whereas DACC = Discretionary accruals; DRPT = indicator variable of 1 for a priori adverse RPT; VRPT $=$ value of RPT divided by market value of equity; VRPT_DRPT = interaction variable VRPT with DRPT; DCG CG = dummy variable, 1 if the company has a CG index above the median value of the sample firms (high level of CG mechanism) or 0 if the index is below the median (low level of CG mechanism); DRPT_DCG = interaction variable between DRPT with DCG; we use same control variables as in the model (a).

We use cross sectional Kaznik (1999) model to calculate discretionary accruals:

$\mathrm{TACC}_{\mathrm{it}} / \mathrm{TA}_{\mathrm{i}, \mathrm{t}-1}=\alpha_{1}\left(1 / \mathrm{TA}_{\mathrm{i}, \mathrm{t}-1}\right)+\alpha_{2}\left(\Delta \mathrm{REV}_{\mathrm{it}}-\Delta \mathrm{REC}_{\mathrm{it}}\right) /$

$\mathrm{TA}_{\mathrm{i}, \mathrm{t}-1}+\alpha_{3} \mathrm{PPE}_{\mathrm{i}, \mathrm{l}} / \mathrm{TA}_{\mathrm{i}, \mathrm{t}-\mathrm{l}}+\alpha_{3} \Delta \mathrm{CFO}_{\mathrm{i}, \mathrm{t}} / \mathrm{TA}_{\mathrm{i}, \mathrm{t}-\mathrm{l}}+\varepsilon_{\mathrm{it}}$
Whereas, $\mathrm{TACC}_{\mathrm{it}}=$ total accrual year $\mathrm{t}, \mathrm{TA}_{\mathrm{it}-1}=$ total asset at the beginning of year $\mathrm{t} ; \Delta \mathrm{REV}_{\mathrm{it}}=$ change in revenue between year $\mathrm{t}$ and $\mathrm{t}-1 ; \Delta \mathrm{REC}_{\mathrm{it}}=$ change in receivables between year $\mathrm{t}$ and $\mathrm{t}-1 ; \mathrm{PPE}_{\mathrm{it}}=$ gross property, plant, and equipment in year $\mathrm{t} ; \Delta \mathrm{CFO}_{\mathrm{it}}=$ change in cash flows from operation between year $\mathrm{t}$ and $\mathrm{t}-1$.

\section{RESULTS AND DISCUSSION}

The results of the sample selection is as shown in Table 1.

Table 2 shows a summary of the descriptive statistics of the sample combined non RPT and RPT

Table 3 shows a summary of descriptive statistics of sub-sample RPT.

From the table 2 and table 3 , we can see that average discretionary accruals amounted to 0.020455 of the combined sample RPT and non-RPT with a standard deviation of 0.1282 . While in the RPT sub-sample, the average discretionary accrual is 0.011588 , with a standard deviation of 0.139245 . It can be seen that the standard deviation of discretionary accruals for the RPT sub-sample is higher than the combined samples (RPT and non-RPT), which showed a high variation in earnings management of companies that engage in RPT.

Average CG index in RPT group of samples is $63.87 \%$, almost equal to the average CG index of the combined group RPT and non-RPT amounting to $62.86 \%$, which means that the monitoring mechanism

Table 1. Samples

\begin{tabular}{lccc}
\hline \multicolumn{1}{c}{ Description } & RPT & Non-RPT & Total \\
\hline Transactions identified in the corporate actions & 178 & 197 & 375 \\
\hline -/- Companies in the financial industry & -24 & -42 & -66 \\
\hline -/- Incomplete data & -20 & -19 & -39 \\
\hline -/- Outlier & -10 & -5 & -15 \\
\hline Total & 124 & 131 & 255 \\
\hline
\end{tabular}


Table 2. Descriptive Statistic - sampel RPT and non-RPT

\begin{tabular}{lcccccccc}
\hline & DACC & D1RPT & D2RPT & CG & PROF & GROW & LEV & LNSIZE \\
\hline Mean & 0.020455 & 0.321569 & 0.164706 & 0.628699 & 0.062649 & 3.513061 & 0.337076 & 27.05597 \\
\hline Median & 0.025613 & 0.000000 & 0.000000 & 0.628543 & 0.033394 & 1.766670 & 0.316760 & 27.17689 \\
\hline Maximum & 0.586195 & 1.000000 & 1.000000 & 0.851664 & 0.936425 & 23.16880 & 0.977696 & 31.59428 \\
\hline Minimum & -0.705757 & 0.000000 & 0.000000 & 0.460837 & 0.000171 & 0.051194 & 0.000320 & 17.98481 \\
\hline Std. Dev. & 0.128200 & 0.467997 & 0.371644 & 0.068114 & 0.097290 & 4.526681 & 0.219776 & 2.147442 \\
\hline
\end{tabular}

Table 3. Descriptive Statistic - sub sampel RPT

\begin{tabular}{lcccccccc}
\hline & DACC & DRPT & VRPT & CG & PROF & GROW & LEV & LNSIZE \\
\hline Mean & 0.011588 & 0.661290 & 0.393542 & 0.638735 & 0.062648 & 4.429502 & 0.363013 & 27.51011 \\
\hline Median & 0.013852 & 1.000000 & 0.332002 & 0.632240 & 0.035926 & 2.450152 & 0.330302 & 27.54334 \\
\hline Maximum & 0.586195 & 1.000000 & 2.516103 & 0.813673 & 0.936425 & 21.47769 & 0.817004 & 31.59428 \\
\hline Minimum & -0.705757 & 0.000000 & 0.000173 & 0.480728 & 0.000316 & 0.105712 & 0.000320 & 17.98481 \\
\hline Std. Dev. & 0.139245 & 0.475191 & 0.520480 & 0.066221 & 0.103334 & 4.856170 & 0.221508 & 2.327266 \\
\hline
\end{tabular}

against companies that engage in RPT are not different. When compared to average CG index for all companies listed on IDX issued by the IICD in 2005 amounted to $61.26 \%$ and in 2007 was $64.97 \%$, then the average index of CG on companies engage in RPT do not significantly differ from average CG index of all companies listed in IDX.

The result of regression model (a) as shown in Table 4.

Table 4 presents the result of hypothesis $\mathrm{H} 1 \mathrm{a}, \mathrm{H} 1 \mathrm{~b}$ and H1c. It shows that the average discretionary accrual of companies that involve in a priori adverse RPT will have higher discretionary than companies that do not perform RPT. The average discretionary accrual of companies that involve in a priori adverse RPT, is different than companies that do not involve in RPT. It can be said that companies involve in RPT has not different average discretionary accrual compared to companies that do not involve in RPT. It means that the H1a and H1b cannot be accepted. The table 4 also shows that stronger CG will reduce the activity of aggressive earnings management. It means we can accept hypothesis $1 \mathrm{c}$, that CG is thought to function as an oversight mechanism to aggressive earnings management actions to meet specific goals of management or controlling shareholders that can expropriate minority shareholders. These results are consistent with research Liu and Lu (2007) and Chen $\&$ Elder (2007). These results are also consistent with studies Lara \& Osma (2007), that stronger CG is associated with smaller discretionary accruals, which means firms are more conservative.

The control variable Leverage is not consistent with debt covenant hypothesis. It is also found that the control variable, Size, is not consistent with the political cost hypothesis. The Size variable is consistent with the views of Lobo \& Zhou (2006) and DeFond \& Park (1997) that large-sized companies is more flexible to engage in earnings management because the transaction is more complex than smaller companies, making it difficult to detect. This action is intended to increase corporate profits to meet the expectations of shareholders.

Further, since the existence of RPT does not have a different effect on discretionary accrual, we cannot be sure to say that the RPT is an efficient transaction. 
Tabel 4. Regression Result - Model (a) DACCi $=\alpha_{0}+\alpha_{1}$ D1RPT $_{i}+\alpha_{2}$ D2RPT $_{\mathrm{i}}+\alpha_{3} \mathrm{CG}_{\mathrm{i}}+\alpha_{4}$ D1YEAR $_{\mathrm{i}}+\alpha_{5} \mathrm{D}$ YEAR $_{\mathrm{i}}+\alpha_{6} \mathrm{D}$ YEAR $_{\mathrm{i}}+$
$\alpha_{7}$ PROF $_{\mathrm{i}}+\alpha_{8} \mathrm{GROW}_{\mathrm{i}}+\alpha_{9} \mathrm{LEV}_{\mathrm{i}}+\alpha_{10} \mathrm{SIZE}_{\mathrm{i}}+\mathrm{e}_{\mathrm{i}}$

\begin{tabular}{|c|c|c|c|c|c|}
\hline \multicolumn{6}{|c|}{ Dependent Variable : DACC } \\
\hline \multicolumn{6}{|l|}{ Method: OLS } \\
\hline \multicolumn{6}{|c|}{ Sample: 255 (RPT and non-RPT) } \\
\hline Variable & Hypothesis & Coefficient & Standard Error & t-statistic & p-value \\
\hline D1RPT & H1a: + & -0.018734 & 0.018424 & -1.016793 & 0.1551 \\
\hline D2RPT & H1b: +/- & -0.032769 & 0.022937 & -1.428666 & 0.1544 \\
\hline $\mathrm{CG}$ & H1c: - & -0.326709 & 0.134220 & -2.434132 & $0.0078^{* * *}$ \\
\hline D1YEAR & & 0.032222 & 0.023438 & 1.374784 & 0.1705 \\
\hline D2YEAR & & 0.051348 & 0.022626 & 2.269408 & $0.0241^{* *}$ \\
\hline D3YEAR & & 0.025585 & 0.029338 & 0.872072 & 0.3840 \\
\hline PROF & $+/-$ & -0.073417 & 0.083687 & -0.877275 & 0.3812 \\
\hline GROW & + & 0.000727 & 0.001882 & 0.386005 & 0.3499 \\
\hline LEV & + & -0.077694 & 0.036236 & -2.144115 & $0.0165^{* *}$ \\
\hline LnSIZE & $+/-$ & 0.013425 & 0.004431 & 3.030054 & $0.0027 * * *$ \\
\hline $\mathrm{C}$ & & -0.130436 & 0.111513 & -1.169694 & 0.2433 \\
\hline R-squared & & 0.088971 & & & \\
\hline Adjusted R-squared & & 0.051634 & & & \\
\hline F-statistic & & 2.382916 & & & \\
\hline Prob(F-statistic) & & 0.010367 & & & \\
\hline Durbin-Watson stat & & 1.996508 & & & \\
\hline
\end{tabular}

So we need to carry out the second regression model with a sub-sample of firms that conduct RPT.

The result in table 5 suggests that discretionary accruals of companies with a priori adverse RPT will not be higher than companies with a priori not adverse RPT. Thus, hypothesis $2 \mathrm{a}$ is not accepted, which not indicate a higher incentive to manage earnings to increase income in a company that perform a priori adverse RPT.

The size of RPT does not necessarily indicate that the company engaged in earnings management actions. Thus, hypothesis $2 \mathrm{~b}$ is not accepted, means the amount (size) of RPT has no effect on discretionary accruals. Similarly, hypothesis 2c was also not accepted, that the effect of the amount (size) of a priori adverse RPT are not more positively associated with discretionary accruals than a priori not adverse RPT. This also means that the actions to increase profits does not depend on its size of transactions.

The result show that strong CG mechanism will reduce aggressive earnings management. Consistent with the results of first hypothesis that use combined sample of RPT and non-RPT, means that the stronger the $\mathrm{CG}$ practices, the more conservative accruals policies been adopted.

Variable GROW is consistent with Mc Nichols (2000), that companies with high growth rates 
Tabel 5. Regression Result - Model (b)

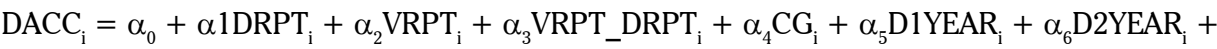
$\alpha_{7}$ D3YEAR $_{\mathrm{i}}+\alpha_{8}$ PROF $_{\mathrm{i}}+\alpha_{9}$ GROW $_{\mathrm{i}}+\alpha_{10} \mathrm{LEV}_{\mathrm{i}}+\alpha_{11} \mathrm{SIZE}_{\mathrm{i}}+\mathrm{e}_{\mathrm{i}}$

Dependent Variable : DACC

Method: OLS

Sample: 124 (RPT)

\begin{tabular}{llllll}
\multicolumn{1}{c}{ Variable } & Hypothesis & Coefficient & Standard Error & t-statistic & p-value \\
\hline DRPT & H2a: + & 0.006301 & 0.032074 & 0.196439 & 0.4223 \\
\hline VRPT & H2b: + - & -0.000945 & 0.043280 & -0.021833 & 0.9826 \\
\hline VRPT_DRPT & H2c: + & 0.030059 & 0.084245 & 0.356805 & 0.3609 \\
\hline CG & - & -0.357389 & 0.206732 & -1.728759 & $0.0433^{* *}$ \\
\hline D1YEAR & & 0.093977 & 0.039943 & 2.352757 & $0.0204^{* *}$ \\
\hline D2YEAR & & 0.127416 & 0.037090 & 3.435326 & $0.0008^{* * *}$ \\
\hline D3YEAR & $+/-$ & 0.062236 & 0.041950 & 1.483576 & 0.1407 \\
\hline PROF & -0.075701 & 0.119588 & -0.633018 & 0.5280 \\
\hline GROW & + & 0.003562 & 0.002624 & 1.357702 & $0.0886^{*}$ \\
\hline LEV & + & -0.048302 & 0.056197 & -0.859503 & 0.1959 \\
\hline LNSIZE & $+/-$ & 0.010824 & 0.006278 & 1.724210 & $0.0874^{*}$ \\
\hline C & -0.147205 & 0.173448 & -0.848698 & 0.3979 \\
\hline
\end{tabular}

\begin{tabular}{ll} 
R-squared & 0.176998 \\
\hline Adjusted R-squared & 0.096167 \\
\hline F-statistic & 2.189737 \\
\hline Prob(F-statistic) & 0.019658 \\
\hline Durbin-Watson stat & 2.048329 \\
\hline
\end{tabular}

$* * *$ significant at $1 \% ; * *$ significant at $5 \% ; *$ significant at $10 \%$

will have a high discretionary accruals. Consistent with previous results, the control variable SIZE has a significant positive effect on discretionery accruals.

After testing the second model, we are still not confident to say that the existence of a priori adverse RPT and the size of transaction do not provide higher incentives to companies to increase income. It is inferred that the effect of RPT to earnings management depends on the mechanism of CG. The third hypothesis test results are summarized in table 6 .
In the third model, when we include interaction variables of DRPT_DCG, the result is different from the previous result (model b). The existence of a priori adverse RPT that previously not significant, now it has significant positive effect to discretionary accruals. This indicates that the influence of the existence of a priori adverse RPT to discretionary accruals depend on the mechanism of CG. Thus the hypothesis $3 \mathrm{a}$ is accepted, which means companies that perform a priori adverse RPT with weak CG, will have a higher discretionary accruals than company that perform a priori not adverse RPT. Companies that perform a priori adverse RPT will increase income to cover possible losses from RPT. 
Tabel 6. Regression Result - Model (C)

$\mathrm{DACC}_{\mathrm{i}}=\alpha_{0}+\alpha_{1} \mathrm{DRPT}_{\mathrm{i}}+\alpha_{2} \mathrm{VRPT}_{\mathrm{i}}+\alpha_{3} \mathrm{DCG}_{\mathrm{i}}+\alpha_{4} \mathrm{VRPT}_{-} \mathrm{DRPT}_{\mathrm{i}}+\alpha_{5} \mathrm{DRPT}_{-} \mathrm{DCG}_{\mathrm{i}}+\alpha_{6} \mathrm{D}_{\mathrm{YYEAR}}+$ $\alpha_{7}$ D2YEAR $_{\mathrm{i}}+\alpha_{8}$ D3YEAR $_{\mathrm{i}}+\alpha_{9}$ PROF $_{\mathrm{i}}+\alpha_{10} \mathrm{GROW}_{\mathrm{i}}+\alpha_{11} \overline{L E V}_{\mathrm{i}}+\alpha_{12} \mathrm{SIZE}_{\mathrm{i}}+\overline{\mathrm{e}}_{\mathrm{i}}$

Variabel Dependen : DACC

Metode: OLS

Sampel: 124 (sampel RPT)

\begin{tabular}{llllll}
\multicolumn{1}{c}{ Variabel } & \multicolumn{1}{c}{ Hipotesis } & \multicolumn{1}{c}{ Koefisien } & Standard Error & t-statistik & p-value \\
\hline DRPT & H3a: + & 0.667311 & 0.199161 & 3.350616 & $0.0005^{* * *}$ \\
\hline VRPT & $+/-$ & -0.010097 & 0.041973 & -0.240555 & 0.8103 \\
\hline VRPT_DRPT & + & 0.035988 & 0.081561 & 0.441241 & 0.3299 \\
\hline DCG & - & 0.044281 & 0.032755 & 1.131890 & 0.1396 \\
\hline DRPT_DCG & H3b: - & -1.034313 & 0.308244 & -3.355502 & $0.0005^{* * *}$ \\
\hline D1YEAR & & 0.098574 & 0.038716 & 2.546068 & $0.0123^{* *}$ \\
\hline D2YEAR & & 0.136646 & 0.035986 & 3.797209 & $0.0002^{* * *}$ \\
\hline D3YEAR & & 0.071359 & 0.040887 & 1.745303 & $0.0837^{*}$ \\
\hline PROF & $+/-$ & -0.093468 & 0.115898 & -0.806467 & 0.4217 \\
\hline GROW & + & 0.004379 & 0.002549 & 1.718124 & $0.0443^{* *}$ \\
\hline LEV & + & -0.062579 & 0.054453 & -1.149235 & 0.1264 \\
\hline LNSIZE & $+/-$ & 0.009552 & 0.005944 & 1.607078 & 0.1109 \\
\hline C & & -0.365759 & 0.163360 & -2.238980 & 0.0272 \\
\hline & & & & & \\
\hline R-squared & & 0.237430 & & & \\
\hline Adjusted R-squared & & 0.154990 & & & \\
\hline F-statistic & & 2.880032 & & & \\
\hline Prob(F-statistic) & & 0.001712 & & & \\
\hline Durbin-Watson stat & & & & & \\
\hline & & & & & \\
\hline
\end{tabular}

*** signifikan $1 \% ; * *$ signifikan $5 \% ; *$ signifikan $10 \%$

These results consistent with the findings of Gordon \& Henry (2005) who said that RPT tend to expropriate the minority shareholders, which is consistent with the hypothesis of a conflict of interest. However, the existence of a priori adverse RPT classified by Cheung et al. (2006) is not an indication that the company will engage in earnings management, because it depends on the mechanism of CG. In this research, it becomes more obvious that the a priori adverse RPT with a weak CG, will result the expropriation of minority shareholders. These results are also consistent with Sherman \& Young (2001) that the RPT is an area that allows for aggressive accounting. The results also conclude that we can accept Hypothesis 3b, that the interaction variable between DRPT and CG is negatively associated with discretionary accruals. It indicates that a strong CG practices will reduce discretionary accruals in companies that involve in a priori adverse RPT. Consistent with previous result (model b) that the earnings management does not depend on the size of transaction, but depends on the existence of a priori adverse RPT and CG mechanisms of the company.

\section{MANAGERIAL IMPLICATIONS}

The implication of this study that the existence of RPT is not necessarily an indication of a 
company engaged in earnings management, but the investors need to see the type of transaction and corporate governance practise. Asset acquisition transactions, asset sales, stock sales, trade relations, and cash payments, including the provision of loan guarantees or loans for property transactions are represent transactions that a priori likely to result in expropriation. If the transaction is conducted by companies with a weak CG practices, then the existence of these transactions could be used as an indication of the companies involved in earnings management actions that increasing income by using its accrual accounting policy, which aims to disguise the numbers in the Financial Statement in order to cover the expropriation.

In addition, strong CG mechanism is proven to reduce the incentive earnings management to increase income in the company that conduct a priori adverse RPT. This result suggests to the investors that they can rely on the company's CG mechanism to prevent earnings management Although not all RPT are adverse, but investors should be alert to the types of RPT which has negative impact to the company. To be able to see the effect of RPT on the company, the investors should analyse and review RPT carefully. Since the regulator (Otoritas Jasa Keuangan [OJK], the Financial Service Authority, in Indonesia) requires listed companies to announce their related party transactions (Kep. BAPEPAM No. KEP-412/BL/2009 about Related Party Transaction and Conflict of Interest), the investors can utilise the corporate announcement about this RPT and conduct necessary review regarding the possible impact of this transactions.

\section{CONCLUSION}

The results of this study indicates that there was no significant difference in the earnings management activities in the companies with RPT and in companies without RPT. This indicates that RPT are not necessarily as an indication that the company involve in earnings management.
These results are consistent with research Gordon \& Henry (2005). Furthermore, it is not consistent with our expectation, that the existence of a priori adverse RPT also can not directly be an indication that the company engage in earnings management to increase income. Earnings management actions that increase income is found at the company that perform a priori adverse RPT with weak corporate governance practise.

The positive effect of a priori adverse RPT to discretionary accruals depends on the company's CG practices. The company with a priori adverse RPT and has a weak CG, is consistent with conflict of interest hypothesis. It is clear that the transaction classified as RPT a priori likely to result in expropriation according to Cheung et al. (2006) is consistent with the hypothesis of conflict of interest. This study shows that a strong $\mathrm{CG}$ practices can reduce the incentive to increase income and earnings management in companies involved in RPT that a priori likely to result in expropriation. It is also found that RPT influence on earnings management does not depend on the size of the dislosed value (amount). Thus it can be said that the incentives of earnings management to cover losses does not depend on the size of RPT, but depends on the presence of a priori adverse RPT and CG mechanisms in the company.

This study has several limitations, it is considered RPT as exogenous variables, whereas, RPT also can treated as endogenous variable because it is also influenced by corporate governance. Short time span of this study (2005 - 2008), may not describe the pattern of earnings management that occurred in companies. The observed earnings management action is limited to accrual policy. This should be investigated further whether companies that conduct a priori adverse RPT will conduct "taking a bath." "Taking a bath" should be done when the company reaches a certain level of loss due to RPT. When the company reaches a certain level of losses, the management possibly did not try to improve profit to cover the impact 
losses of RPT, but possibly cover with "taking a bath". Besides, It should be examined further, the impact of different party involve in RPT, to know in depth the nature and impact on the company.

\section{REFEREN CES}

CFA Institute, (2009). "Related Party Transactions, Cautionary tales for Investors in Asia." Report. Asia Pacific Office of the CFA Institute Center for Financial Market Integrity.

Chen, K. Y., Elder, R. J., \& Hsieh, Y. M. (2007). Corporate governance and earnings management: The implications of corporate governance best-practice principles for Taiwanese listed companies. Journal of Contemporary Accounting \& Economics, 3(2), 73-105.

Cheung, Y. L., Rau, P. R., \& Stouraitis, A. (2006). Tunneling, propping, and expropriation: evidence from connected party transactions in Hong Kong.Journal of Financial Economics, 82(2), 343-386.

DeFond, M. L., \& Jiambalvo, J. (1994). Debt covenant violation and manipulation of accruals. Journal of accounting and economics, 17(1), 145-176.

DeFond, M. L., \& Park, C. W. (1997). Smoothing income in anticipation of future earnings. Journal of accounting and economics, 23(2), 115-139.

Dewan Standar Akuntansi Keuangan (2009). Pernyataan Standar Akuntansi Keuangan (PSAK 7): Pengungkapan Pihak Berelasi. Revisi 2009.

Gao, L., \& Kling, G. (2008). Corporate governance and tunneling: Empirical evidence from China. Pacific-Basin Finance Journal, 16(5), 591-605.

Gordon, E. A., E. Henry and D. Palia, (2004). "Related Party Transactions and Corporate Governance." Advances in Financial Economics, Volume 9: 1-27.

Gordon, E. A., \& Henry, E. (2005). Related party transactions and earnings management. Available at SSRN 612234.

Gordon, E. A., Henry, E., \& Palia, D. (2006). Related party transactions: associations with corporate governance and firm value. In EFA 2004 Maastricht Meeting Paper \& AFA.

Hutapea, W. Damaiyanti, (2008). "Pengaruh Komponen-Komponen Corporate Governance, Proporsi Kepemilikan, Tingkat Hutang, dan Ukuran Perusahaan terhadap Kemungkinan Terjadinya Transaksi Pihak Hubungan Istimewa. Tesis. Program Ilmu Magister Sains Manajemen Keuangan. University of Indonesia.

Jensen, M. and W. Meckling, (1976). "Theory of The Firm: Managerial Behavior, Agency Costs and Ownership Structure. Journal of Financial Economics, 3, 305-360.

Kaznik, R., (1999). "On the Association between Voluntary Disclosure and Earnings Management." Journal of Accounting Research, 37, 57-81.

Kohlbeck, M. J., \& Mayhew, B. W. (2004). Related party transactions. In AAA 2005 FARS Meeting Paper.

LaFond, Ryan and Watts, Ross L., (2008). The Information Role of Conservatism. The Accounting Review, 83, pp. 447.

Lara, J. M. G., Osma, B. G., \& Penalva, F. (2009). Accounting conservatism and corporate governance. Review of Accounting Studies, 14(1), 161-201.

Liu, Q., \& Lu, Z. J. (2007). Corporate governance and earnings management in the Chinese listed companies: A tunneling perspective. Journal of Corporate Finance, 13(5), 881-906.

Lobo, G. J., \& Zhou, J. (2006). Did conservatism in financial reporting increase after the Sarbanes-Oxley Act? Initial evidence. Accounting Horizons, 20(1), 57-73.

Mc Nichols, M. (2000), "Research Design Issues in Earnings Management Studies", Journal of Accounting and Public Policy, $19,313-345$

Ross L., Watts, \& Zimmerman, J. L. (1986). Positive accounting theory. Prentice Hall International.

Sherman, H. D., \& Young, S. D. (2001). Tread lightly through these accounting minefields. Harvard business review, (79), 12935 .

The OECD Principles of Corporate Governance, (2004), www.oecd.org.

Wong, T. J., \& Jian, M. (2003, June). Earnings management and tunneling through related party transactions: Evidence from Chinese corporate groups. In EFA 2003 Annual Conference Paper (No. 549). 